\title{
PENGENALAN DAN PRAKTIK KONSERVASI SUMBER DAYA GENETIK BAGI REMAJA DI LINGKUNGAN KAMPUS UNILAK
}

\author{
E.Mutryarny ${ }^{1}$, T.Wulantika ${ }^{2}$, Endriani $^{3}$
}

\begin{abstract}
ABSTRAK
Indonesia merupakan negara tropis dengan kekayaan sumber daya genetik (plasma nutfah) yang sangat besar. Oleh karena itu, Indonesia termasuk negara dengan megabiodiversity terbesar kedua. Sumberdaya genetik atau plasma nutfah adalah bahan tanaman, hewan, jasad renik, yang mempunyai kemampuan untuk menurunkan sifat dari satu generasi ke generasi berikutnya. Plasma nutfah harus dikonservasi karena plasma nutfah sering mengalami erosi genetik yang mengakibatkan jumlah plasma nutfah semakin menurun. Erosi genetik selain disebabkan oleh manusia juga bisa karena seperti kebakaran hutan, bencana alam, dll.Remaja adalah generasi muda yang a kan berperan besar dalam keberadaan sumber daya genetic dimasa depan. Dewasa ini banyak remaja yang belum memahami arti penting sumber daya genetic, oleh karena itu perlu dilakukan pengenalan dan praktik terhadap konservasi Sumber Daya Genetik pada remaja disekitar kampus Unilak.Kegiatan pengabdian masyarakat ini telah dilaksanakan pada bulan April 2019 dengan cara penyampaian materi terkait keanekaragaman hayati, sumber daya genetic dan plasma nutfah serta upaya konservasi sumber daya genetic dan Praktik langsung terhadap upaya konservasi sumber daya genetik melalui koleksi benih dan pembuatan kebun koleksi plasma nutfah. Hasil dari kegiatan pengabdian masyarakat ini $100 \%$ peserta memahami plasma nutfah, arti penting konservasi sumber daya genetic dan cara yang dapat dilakukan dalam kegiatan konservasi sumber daya genetik. Ditinjau dari segi manfaat kegiatan yang dilakukan terlihat dari awal peserta sudah antusias mengikuti kegiatan ini dengan ditunjukkan hasil kuisioner pre test dan post test $100 \%$ peserta menyatakan kegiatan yang dilakukan bermanfaat.
\end{abstract}

Kata kunci : Erosi Genetik, Konservasi, Plasma Nutfah, Sumber Daya Genetik

\begin{abstract}
Indonesia is a tropical country with a wealth of geneticresources (germplasm). Therefore, Indonesia includingcountries with megabiodiversity is the second largest.Germplasm or genetic resources are plants, animals,remains miniscule, which has the ability to degrade theproperties from one generation to the next. Germplasmshould be konservation because the germplasm oftenexperience genetic erosion which resulted in the decliningnumber of germplasm. In addition to genetic erosion causedby humans could also be because such as forest fires,natural disasters, etc. Teenager is the younger generation that a right plays amajor role in the existence of genetic resources in thefuture. Nowadays many teenagers who have not understoodthe importance of genetic resources, hence the need for theintroduction and practice against the conservation of geneticresources in teens around the campus Unilak. These outreach activities have been conducted in April 2019by way of delivery of the materials related biodiversity andgenetic resources, germplasm and genetic resourceconservation efforts and practices directly against the effortsof conservation of genetic resources through the collectionof seeds and garden making germplasm collections. Theresult of this outreach activity $100 \%$ participants understandthe significance, germplasm conservation of geneticresources and how that can be done in the geneticresources conservation activities. In terms of benefitsactivities conducted out of sight of the initial participantsalready enthusiastically follow these activities withdemonstrated results of
\end{abstract}

\footnotetext{
${ }^{1}$ Dosen Program Studi Agroteknologi,Fakultas Pertanian Universitas Lancang, Kuning.enny57@yahoo.co.id.Trisiawulantika@unilak.ac.id

${ }^{2}$ Dosen Program Studi Agroteknologi,Fakultas Pertanian Universitas Lancang

${ }^{3}$ Dosen Program Studi Agroteknologi,Fakultas Pertanian Universitas Lancang
} 
questionnaire pre test and post test $100 \%$ of the participants stated activities conductedbeneficial.

Keyword:, Genetic Erosion, Conservation, Germplasm,Genetic Resources

\section{Pendahuluan}

Indonesia merupakan negara tropis dengan kekayaan sumber daya genetik (plasma nutfah) yang sangat besar. Oleh karena itu, Indonesia termasuk negara dengan megabiodiversity terbesar kedua. Tingginya tingkat keanekaragaman hayati (biodiversity) plasma nutfah ini karena Indonesia memiliki bentang alam yang luas dengan penyebaran dan kondisi wilayah geografis yang bervariasi. Plasma nutfah adalah salah satu sumber daya alam yang sangat penting dan merupakan modal dasar yang diperlukan dalam mengembangkan industry pertanian.

Plasma nutfah merupakan sumber daya genetik yang diperlukan,salah satunya untuk mengembangkan varietas/kultivar baru (Sumarno dan Zuraida2004). Tingginya keragaman plasma nutfah yang kita milikimembuka peluang bagi upaya mencari, menemukan, memanfaatkan, danmengoptimalkan potensi genetik yang belum tergali.

Sumberdaya genetik atau plasma nutfah adalah bahan tanaman, hewan, jasad renik, yang mempunyai kemampuan untuk menurunkan sifat dari satu generasi ke generasi berikutnya. Pada tanaman, sumber daya genetik terdapat dalam biji, jaringan, bagian lain tanaman, serta tanaman muda dan dewasa.Sumber Daya Genetik adalah material tumbuhan, binatang, atau jasad renik yang mengandung unit-unit yang berfungsi sebagai pembawa sifat keturunan baik yang bernilai actual maupun potensial untuk menciptakan galur, rumpun, atau spesies baru.

Salah satu upaya untuk meningkatkan produktifitas dan kualitas hasil pertanian adalah melalui perbaikan genetik bahan tanaman dengan memanfaatkan sumber daya genetik (SDG) yang berbeda dengan material yang telah ada. Keanekaragaman genetik dalam plasma nutfah merupakan bahan dasar yang diperlukan dalam program untuk menghasilkan varietas dan hibrida unggul serta berbagai penemuan dan inovasi. Untuk itu diperlukan ketersediaan SDG dengan tingkat keragaman yang tinggi sebagai sumber keragaman genetik. Tersedianya SDG yang didukung oleh sistem pengelolaan yang kuat akan memacu percepatan perakitan tanaman unggul.

Mengingat bahwa plasma nutfah adalah salah satu sumber daya alam yang sangat penting, karena tanpa plasma nutfah kita tidak dapat memuliakan tanaman, membentuk kultivar baru/ras baru. Oleh sebab itu, Indonesia sebagai salah satu negara yang kaya dengan keragaman genetik/sumber daya hayati perlu memikirkan penanganan keragaman genetik tersebut agar tidak punah. Dengan terpeliharanya keragaman genetik maka pada akhirnya akan menunjang programpemuliaan tanaman kearah yang lebih maju.

Plasma nutfah harus dikonservasi karena plasma nutfah seringmengalami erosi genetik yang mengakibatkan jumlah plasma nutfah semakin menurun. Erosi genetik selain disebabkan oleh manusia juga bisa karena seperti kebakaran hutan, bencana alam, dll.

Remaja adalah generasi muda yang akan berperan besar dalam keberadaan sumber daya genetic dimasa depan. Dewasa ini banyak remaja yang belum memahami arti penting sumber daya genetic, oleh karena itu perlu dilakukan pengenalan dan praktik terhadap konservasi Sumber Daya Genetik pada remaja disekitar kampus Unilak.

\section{Solusi yang ditawarkan}

Terkait permasalahan mitra maka dibutuhkan solusi pemecahan masalahnya antaralain :

1. Memberikan pemahaman tentangtentangsumber daya genetik

2. Memberikan ilmu pengetahuan tentang keragaman hayati

3. Memberikan ketrampilan dalam usaha konservasi sumber daya genetik 


\section{Target dan Luaran}

Kegiatanpengabdiankepadamasyarakatinisasarannyaadalah Remaja disekitar kampus Unilak. Targetluaranyangingindicapai dari kegiatan iniadalah :

1. Kelompok Remaja disekitar kampus Unilak mampu memahami arti pentingsumber daya genetic

2. Kelompok Remaja disekitar kampus Unilakmemiliki ilmu pengetahuan tentang keragaman hayati

3. Kelompok Remaja disekitar kampus Unilak memiliki ketrampilan dalam usaha konservasi sumber daya genetic

\section{Metode Pelaksanaan}

Adapun metode yang digunakan untuk mencapai tujuan adalah :

1. Penyebaran kuisioner untuk melihat pengetahuan awal

2. Pemberian materi mengenai keanekaragaman hayati, sumber daya genetic dan plasma nutfah serta upaya konservasi sumber daya genetic.

3. Praktik upaya konservasi sumber daya genetik melalui koleksi benih, dan pembuatankebun koleksi bibit

Alat yang digunakan : Botol selai, Kertas label, alat tulis, polybag, rak koleksi, rumah koleksi sederhana, gembor, cangkul. Sedangkan bahan yang digunakan : tanah,pupuk kandang,silica gel,dll

Cara Kerja :

1. Koleksi Benih

Benih yang akan dikoleksi dimasukkan ke dalam botol selai kemudian diberi label dengan format sebagai berikut :

\begin{tabular}{|l|l|}
\hline Nama Kolektor & \\
\hline Tanggal Koleksi & \\
\hline Nama Benih & \\
\hline Species & \\
\hline
\end{tabular}

2. Pembuatan Kebun Koleksi

Kebun koleksi dibuat di kebun percobaan, Fakultas Pertanian Universitas Lancang Kuning dengan cara menempatkan koleksi bibit pada plot yang dibuat sedemikian rupa.

\section{Hasil Dan Pembahasan}

Kegiatan pengabdian ini dimulai dengan tahap perencanaan. Tim pengabdian sebelumnya telah berkordinasi dengan ketua kelompok remaja di lingkungan kampus Unilak pada hari Jumat, tanggal 5April 2019.Maksud, tujuan, rancangan dan beberapa teknis yang berkaitan dengan pelaksanaan kegiatan terlebih dahulu disampaikan kepada ketua kelompok remaja. Adapun implementasi dari kegiatan ini dilaksanakan di ruang sidang dan lahan percobaan Fakultas Pertanian,Universitas Lancang Kuning pada hari Senin 8 April 2019.

Kegiatan diawali dengan pemberian pengetahuan mengenai arti penting sumber daya genetic , keragaman hayati dan penjelasan terkait usaha yang dapat dilakukan untuk konservasi sumber daya genetic. Sebelum dilakukan kegiatan pengabdian dimulai, terlebih dahulu peserta diminta mengisi kuisioner yang telah disediakan. Berikut tabel hasil 
pengukuran pengetahuan peserta pengabdian masyarakat sebelum dan sesudah pembekalan materi.

Tabel 1. Rekapitulasi Hasil Post Test dan Pre Test

\begin{tabular}{|l|l|l|l|l|l|}
\hline No & \multicolumn{1}{|c|}{ Uraian } & \multicolumn{2}{l|}{ Prosentase Pre Test } & \multicolumn{2}{l|}{ Prosentase Post Test } \\
\cline { 3 - 6 } & & Sudah & Belum & Sudah & Belum \\
\hline 1. & $\begin{array}{l}\text { Apakah sudah pernah } \\
\text { mendengar istilah } \\
\text { Konservasi Sumber Daya } \\
\text { Genetik ? }\end{array}$ & 32,4 & 67,6 & 100 & 0 \\
\hline 2. & $\begin{array}{l}\text { Sudah tahukah dengan } \\
\text { Plasma Nutfah? }\end{array}$ & 48,65 & 51,35 & 100 & 0 \\
\hline 3. & $\begin{array}{l}\text { Sudah tahukah dengan arti } \\
\text { penting Konservasi Sumber } \\
\text { Daya Genetik? }\end{array}$ & 29,73 & 70,27 & 100 & 0 \\
\hline 4. & $\begin{array}{l}\text { Pernahkan melakukan } \\
\text { Kegiatan Konservasi } \\
\text { Sumber Daya Genetik? }\end{array}$ & 18,9 & 81,1 & 100 & 0 \\
\hline 5. & $\begin{array}{l}\text { Sudah tahukah dengan cara } \\
\text { pembuatan Kebun Koleksi } \\
\text { Plasma Nutfah ? }\end{array}$ & 10,8 & 89,2 & 100 & 0 \\
\hline No Uraian & & \multicolumn{2}{|c|}{ Prosentase Pre Test } & Prosentase Post Test \\
\cline { 2 - 6 } & Ya & Tidak & Ya & Tidak \\
\hline 1 & $\begin{array}{l}\text { Menurut saudara/i kegiatan } \\
\text { yang dilaksanakan } \\
\text { bermanfaat }\end{array}$ & 100 & 0 & 100 & 0 \\
\hline
\end{tabular}

Berdasarkan rekap hasil pre test dapat dilihat bahwa peserta yang sudah pernah mendengar istilah Konservasi Sumber Daya Genetik hanya 32,4\%, yang sudah tahu dengan Plasma Nutfah hanya $48,65 \%$, yang sudah tahu dengan arti penting Konservasi Sumber Daya Genetik 29,73\%, dan 18,9\% yang sudah Pernah melakukan Kegiatan Konservasi Sumber Daya Genetik serta $10,8 \%$ yang sudah tahu dengan cara pembuatan Kebun Koleksi Plasma Nutfah. Setelah dilakukan kegiatan pengabdian dan diberikan soal post test terjadi peningkatan presentase yang awalnya dibawah $50 \%$ menjadi $100 \%$..

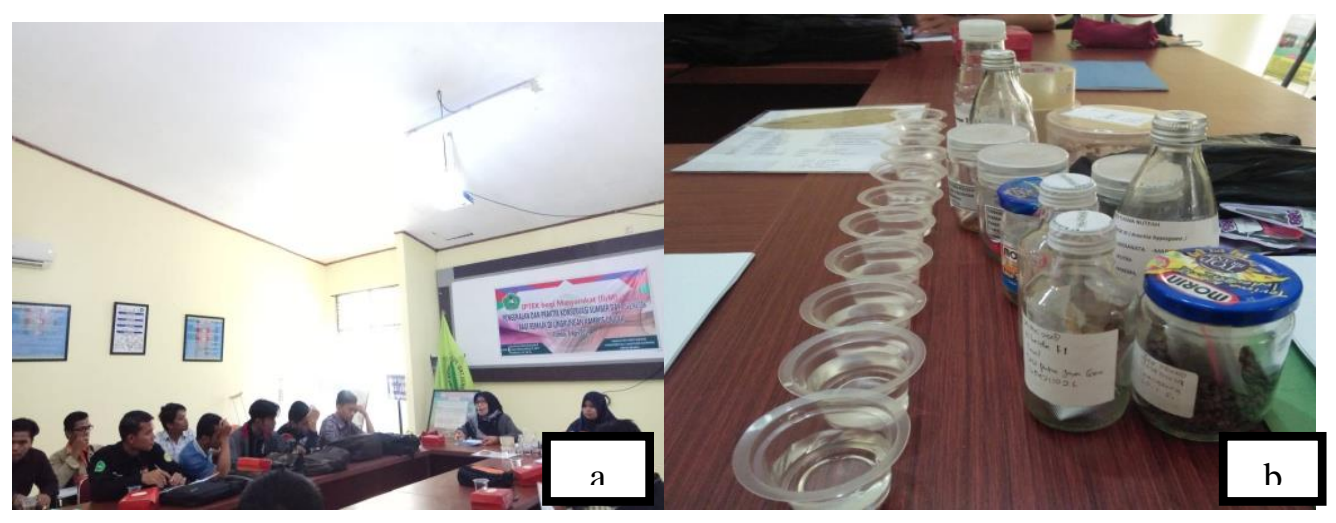



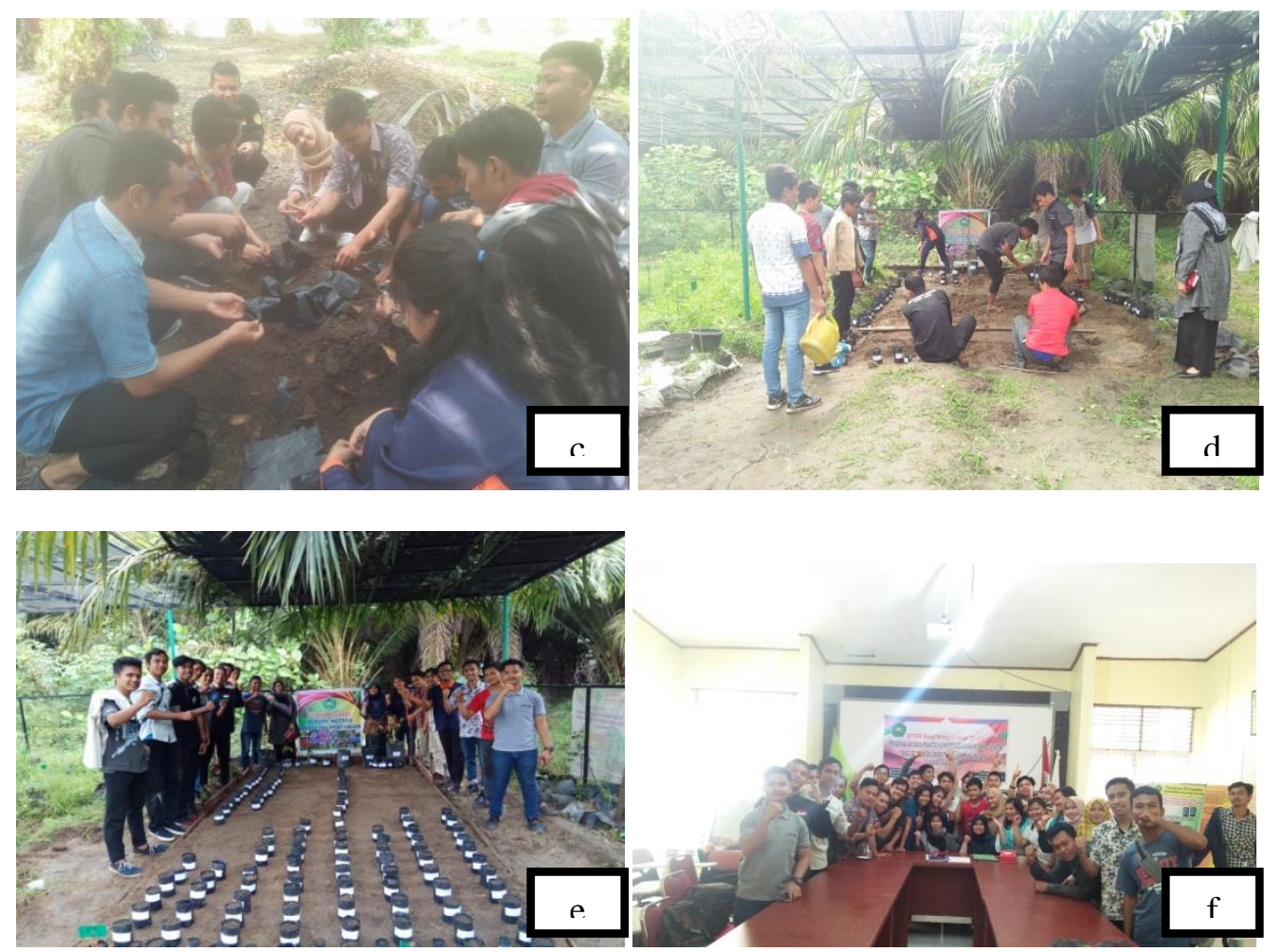

Gambar 2. a.Penyampaian materi dan pemberian pemahaman dari tim pengabdian

b.Botol koleksi benih dan air untuk perendaman benih

c.Pengisian Polybag

d.Pembuatan Kebun Koleksi

e.Foto Bersama di Kebun Koleksi Plasma Nutfah

f.Foto Bersama dengan peserta pengabdian masyarakat

\section{Kesimpulan dan Saran}

Hasil evaluasi yang diambil dari data kuisioner peserta kegiatan dapat disimpulkan bahwa :

1.Hasil evaluasi pengenalan dan praktik konservasi sumberdaya genetic bagi remaja disekitar kampus Unilak, 100\% peserta memahaminya

2.Ditinjau dari segi manfaat kegiatan yang dilakukan terlihat dari awal peserta sudah antusias mengikuti kegiatan ini dengan ditunjukkan hasil kuisioner pre test dan post test $100 \%$ peserta menyatakan kegiatan yang dilakukan bermanfaat.

\section{Daftar Pustaka}

Ducker, Peter F. 1985. Inovasi dan Kewiraswataan, Praktek dan DasarDasar.Erlangga. Jakarta.

Goenadi, D.H. \& Isroi. 2003. Aplikasi Bioteknologi dalam Upaya Peningkatan Efisiensi Agribisnis yang Berkelanjutan. Makalah Lokakarya Nasional Pendekataan Kehidupan Pedesaan dan Perkotaan dalam Upaya Membangkitkan Pertanian Progresif, UPN "Veteran" Yogyakarta, 8-9 Desember 2003.

Huttner, S.L. 2003. Biotechnology and Food. University of California Systemwide. 
Nono Carsono, 2008. Peran Pemuliaan Tanaman dalam Meningkatkan Produksi Pertanian di Indonesia. Disampaikan dalam Seminar on Agricultural Sciences Mencermati Perjalanan

Revitalisasi Pertanian, Perikanan dan Kehutanan dalam Kajian terbatas bidang Produksi Tanaman, Pangan, di Tokyo. 